\title{
The Effect of Green Marketing, Brand Image, And Service Quality on The Decision to Stay at Greenhost Boutique Prawirotaman Yogyakarta
}

\author{
${ }^{1}$ C. Catur Widayati; ${ }^{2}$ Purnamawati Helen Widjaja; ${ }^{3}$ Moh. Mukhsin; ${ }^{4}$ Era Ernawati \\ ${ }^{1,4}$ Faculty of Economics and Business, Universitas Mercu Buana, Indonesia \\ ${ }^{2}$ Faculty of Economics and Business, Universitas Tarumanagara, Indonesia \\ ${ }^{3}$ Faculty of Economics and Business, Universitas Sultan Ageng Tirtayasa, Indonesia \\ ${ }^{1}$ E-mail:catur.widayati@mercubuana.ac.id/ /christinewijaya73@yahoo.co.id \\ ${ }^{2}$ Email: purnamawatiw@fe.untar.ac.id
}

\begin{abstract}
This study aims to determine the effect of Green Marketing, Brand Image, and Service Quality on the Decision to Stay at Greenhost Boutique Prawirotaman, Yogyakarta. The subjects in this study were consumers who had stayed at Greenhost Boutique Prawirotaman, Yogyakarta, in the DKI Jakarta area. The sample used in this study was 170 respondents. The sampling method was carried out by the purposive sampling method. This study uses SEM data analysis techniques and data processing using PLS. This study indicates that Green Marketing has a positive and significant effect on the decision to stay, brand image has a positive and significant effect on the decision to stay, and service quality has a positive and significant effect on the decision to stay.

Keywords: green marketing, brand image, service quality, decision to stay

DOI: $10.7176 / \mathrm{NMMC} / 99-05$

Publication date: November $30^{\text {th }} 2021$

\section{INTRODUCTION}

Environmental and health problems directly and indirectly caused by human activities, both in science and technology, agriculture, economics, and business, have become a central issue in all circles (Manongko, 2015). Public awareness in various parts of the world about the importance of preserving the environment is increasing. Situmorang (2011), in Sugianto's research (2017), suggests that public awareness in various parts of the world about the importance of preserving the environment is increasing. The occurrence of global warming has made people more careful in using various products which are feared to increase the level of global warming to a level that is harmful to humanity.
\end{abstract}

Table 1. Environmental Quality Index (EQI) of the Special Region of Yogyakarta

\begin{tabular}{llll}
\hline EQI Yogyakarta & EQI Yogyakarta & EQI Yogyakarta & EQI Yogyakarta \\
2015 & 2016 & 2017 & 2018 \\
\hline 46,70 & 50,51 & 57,65 & 55,36 \\
\hline
\end{tabular}

Source: menlhk.go.id. (2019)

Based on Table 1, it can be seen that nationally the quality of the Indonesian environment has increased, namely in 2017 by 57.65 . The increase in the environmental quality index is caused by domestic waste such as garbage, factory waste, the increasing number of vehicles that cause air pollution, and chemicals in the production process. In the research of Arimbawa \& Ekawati (2017), the pressure on environmental issues is impossible to ignore. Companies must develop new business models that can fulfill green trends that are popular today, considering that existing companies mostly contribute to global warming.

Marketing products that use materials that do not damage the environment is now known as green products. In the green marketing steps, many producers have carried out that responded positively following consumers by paying attention to the marketing process of products and services. The safe characteristics for the environment and improving product quality will help consumers decide where the quality brand offered is by what consumers expect of the product can be an important factor in making decisions in purchasing (Purnama, \& Adi, 2019).

Yogyakarta is one of the places in Indonesia that can be used as a place of choice for travel or family recreation. Yogyakarta deserves to be one of the places of choice for traveling because it has various tourist 
attractions ranging from cultural tourism to natural scenery. In addition, Yogyakarta's history can also attract tourists to choose Yogyakarta as a tourist destination (Atma, 2016 in Rani, \& Ardhyanto, (2018). It can be seen in Table 2 the level of tourist visits to Yogyakarta.

Table 2. Number of tourist visits to the city of Yogyakarta

\begin{tabular}{lcc}
\hline Year & $\begin{array}{l}\text { Number of domestic } \\
\text { tourists }\end{array}$ & $\begin{array}{l}\text { Number of International } \\
\text { Tourists }\end{array}$ \\
\hline 2016 & 3.150 .834 & 396.518 \\
2017 & 3.459 .116 & 435.655 \\
2018 & 3.653 .240 & 450.000 \\
\hline
\end{tabular}

Source: yogyakarta.bps.go.id (2019)

Based on statistical data from the Yogyakarta Tourism Office, tourist visits to Yogyakarta have increased every year. In the last three years (2016-2018), tourist visits to Yogyakarta have increased significantly. The development of the city of Yogyakarta is increasingly expanding, especially in the tourism sector. Among the many hotels in Yogyakarta, Greenhost Boutique Hotel Yogyakarta, a hotel with the Eco Green hotel concept, is a new target for tourists.

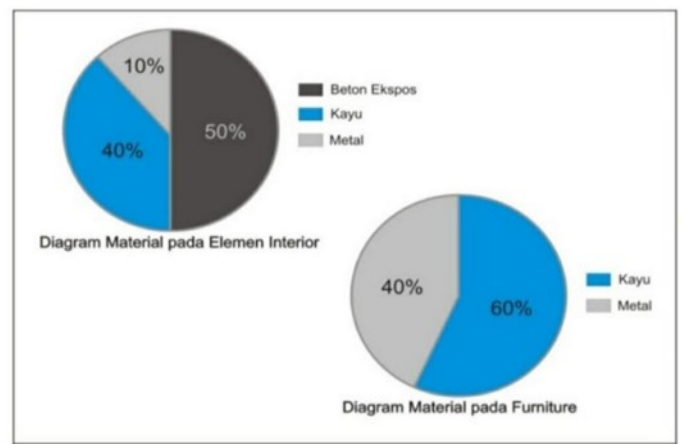

Figure 1. Diagram of the use of environmentally friendly materials

Source: processed data (2019)

The pie chart is based on the amount of material in the room elements and furniture of the Greenhost hotel. Interior elements (floor, walls, ceiling) use $50 \%$ concrete, $40 \%$ wood and $10 \%$ iron. While the furniture uses wood as much as $60 \%$ and $40 \%$ uses metal materials. With these data, it can be concluded that environmentally friendly materials are the most widely used. This strategy makes visitors interested in staying at Greenhost Boutique Prawirotaman, Yogyakarta. The following table shows the number of visitors staying at Greenhost Boutique Prawirotaman, Yogyakarta.

Table 3. Number of Visitors Staying in, Yogyakarta

\begin{tabular}{ll}
\hline Year & Number of Guests \\
\hline 2016 & 47.678 \\
2017 & 48.554 \\
2018 & 46.756 \\
2019 & 30.129 \\
\hline
\end{tabular}

Source: Front-Office Dept. Greenhost Boutique Prawirotaman, Yogyakarta. 
Based on Table 3 above, the number of visitors staying at Greenhost Boutique Prawirotaman, Yogyakarta, decreased in 2019. It was due to a large number of new hotel establishments, both non-star or star hotels, and the proliferation of guest houses in Yogyakarta. Greenhost Boutique Prawirotaman's efforts to increase the number of guests staying at Greenhost Boutique Prawirotaman are by carrying out promotional strategies and collaborating with travel agents.

To strengthen the results of the existing phenomena, the researchers conducted a pre-survey which was distributed to consumers who had stayed at Greenhost Boutique Prawirotaman, Yogyakarta, with a sample of 50 respondents distributed to consumers using google form. This research was conducted referring to previous research, which according to Panungkelan et al. (2018), said that Green Marketing influenced the decision to stay. In addition, research from Jumiati et al., (2017) states that Brand Image influences Staying Decisions. Furthermore, research conducted by Permadi et al., (2019) says that Service Quality influences Staying Decisions.

In this study, the researchers tried to create a different concept from previous researchers, which raised more about the variables of green marketing and brand image; this is what makes this research different from previous researchers. The problems raised in this study are as follows: (1) Does Green Marketing affect the decision to stay at Greenhost Boutique Prawirotaman, Yogyakarta?; (2) Does Brand Image affect the Decision to Stay at Greenhost Boutique Prawirotaman, Yogyakarta?; (3) Does Service Quality affect the Decision to Stay at Greenhost Boutique Prawirotaman, Yogyakarta?

While the objectives of the research are: (1) To find out that Green Marketing has a significant effect on the decision to stay at Greenhost Boutique Prawirotaman, Yogyakarta; (2) To find out Brand Image has a significant effect on the decision to stay at Greenhost Boutique Prawirotaman, Yogyakarta; (3) To find out Service Quality has a significant effect on the decision to stay at Greenhost Boutique Prawirotaman, Yogyakarta.

\section{LITERATURE REVIEW}

\section{Green Marketing}

The American Marketing Association (AMA) in Hawkins and Mothershaugh (2010) defines green marketing as a process of marketing products that are assumed to be safe for the environment. Green marketing can be said to offer products that are only environmentally friendly and include the production process, packaging changes, and product modification activities (Dimyati \& Sukarno, (2018). This definition is strengthened by the opinion of Polonsky (1995) in Sumarwan et al., (2012), which states that green marketing is not just marketing environmentally friendly products but demands a reorientation and environmental responsibility from all areas, activities, and departments of an organization. So, it can be said that green marketing is a concept that refers to meeting consumer needs by trying to minimize the impact of damage to the environment. As proposed by marketing scholars, other definitions of green marketing include social marketing, ecological marketing, or environmental marketing. Green marketing can be defined as a process of marketing products that are assumed to be safe for the environment (Agustin, 2015).

In Agustin's research (2015), it is stated that green marketing is also part of the overall corporate strategy because it must apply a conventional marketing mix consisting of products, prices, places, or distribution channels, and promotions are as follows:

1. Green Products. Classifying an environmentally friendly product is a product that uses environmentally safe materials, is energy efficient, and uses materials from renewable resources.

2. Green Price. Companies that implement a green marketing strategy will set a higher price than competitors' products. The higher costs incurred by green marketing implementing companies due to obtaining certification are the factor that causes the price of environmentally friendly products to be more expensive.

3. Green Place. Each company must decide how to make the product available to consumers. Environmentally friendly distribution channels must pay attention to the convenience of consumers in obtaining products without having to spend a lot of energy and fuel. Some companies that produce environmentally friendly products sell their products through authorized distributors to maintain premium product quality.

4. Green Promotion. The main key to a green marketing strategy is credibility. Promotion of environmentally friendly products can change consumer habits, for example, the perception of consumers who initially use plastic bags to use recycled bags that can be used many times and do not harm the environment.

\section{Brand Image}

Companies must have a brand that is different from their competitors and a brand image that is embedded in the minds of customers. According to Kotler and Keller (2012), brand image describes the extrinsic nature of 
a product or service, including how the brand seeks to meet customers' psychological or social needs. Brand image is a set of perceptions and beliefs that customers have of a brand reflected through the associations that exist in the customer's memory. According to Tjiptono (2014) in Iskandar's (2020) research, Brand Image has several benefits, namely, economic benefits, functional benefits, and psychological benefits. The three benefits affect the company in selling its products to consumers and make consumers fascinated. Meanwhile, Soltani (2016) argues that brand image is a brand image that includes knowledge, opinions from customers, and nonphysical characteristics and physical products, images that customers give to products. According to Sangadji (2013) in the research of Tyas and Kenny (2016). The components that make up the brand image are as follows: (a) Brand Association, a collection of entities associated with a brand. (b) Brand Association Support is a consumer response to a product brand's attributes, benefits, and beliefs based on their research. (c) Strength of Brand Association, consumers will remember the impression they perceive from the product after consuming a product. $d$. The uniqueness of Brand Association, if a product has a characteristic that distinguishes it from other products, the product will be remembered by consumers.

\section{Service Quality}

According to Tjiptono (2014), service quality is centered on efforts to fulfill customer needs and desires and the accuracy of delivery to balance customer expectations. In the research of Gulla et al., (2015), quality is a dynamic condition related to products, services, people, processes, and the environment that meet or exceed expectations. Service quality is the key to measuring customer satisfaction. If performance fails to meet customer expectations, the customer will be dissatisfied. If the performance matches the customer's expectations, the customer will be satisfied. If the performance exceeds customer expectations, the customer will be very satisfied and happy (Kotler \& Keller, 2009 in Wardhana, A. 2015). Some people define it as conformity to requirements or demands, suitability for use in continuous improvement, free from damage or defects, meeting customer needs, and doing everything that can give a happy effect (Tjiptono, 2004 in Prabatha's research, et al., 2020).

In the research of Mahendra \& Cempena (2020), it is stated that there are factors that affect service, namely expected service, and perceived service. If the service received follows what is expected, then the service is said to be good or positive. According to Yosep's research (2016), service quality is more related to time and interaction between employees and customers. The concept of service quality is an assessment factor that reflects consumer perceptions of five specific dimensions of service performance.

\section{Purchasing Decision}

Kotler (2014) states that purchasing decisions are actions from consumers to buy or not to buy products. Of the various factors that influence consumers in purchasing a product or service, usually consumers always consider the quality, price and products that are already known by the public. Meanwhile, according to (Peter \& Olson, 2013) in the research of Permana et al., (2018), said the purchase decision is an integration process used to combine knowledge to evaluate two or more alternative behaviors and choose one of them.

According to Nugraheni and Dwiyanto (2015) in the research of Riyanto and Masjud (2017), product attribute factors are factors that can improve purchasing decisions taken by consumers and affect buying interest as a determinant of success in increasing the number of consumer purchasing decisions. This factor is used by consumers in forming buying interest in the product and as a consideration in making decisions to purchase a product.

Purchasing decision making is an important sub-discussion in the field of marketing, which studies how individuals, groups and organizations choose, buy, use and utilize goods, services, ideas or experiences in order to satisfy their needs and desires (Isa et al., 2018). According to Mangifera et al., 2019 in the research of Isa and Istiqomah (2020) purchasing decision making is very important because of the increasingly fierce level of competition in fighting over consumer decisions in choosing products to meet their needs and desires.

\section{Hypothesis}

Based on the above framework, researchers can make the following hypotheses:

H1: Green Marketing affects Staying Decisions.

$\mathrm{H} 2$ : Brand Image affects the decision to stay.

H3: Service Quality affects the decision to stay.

\section{METHODS}

The population in this study is the people of the DKI Jakarta area who have stayed at Greenhost boutique Prawirotaman, Yogyakarta. The sampling method was carried out by the purposive sampling method. According to Jogiyanto (2016), Purposive Sampling is a sampling technique from the population-based on certain criteria. 
In this study, the number of samples used was 170 respondents, where the sample was determined using the Hair formula. In this study, the data collection technique used a questionnaire that the researchers distributed to the people of the DKI Jakarta area who had stayed at Greenhost Boutique Prawirotaman, Yogyakarta. The data analysis method in this study uses the Smart PLS 3.0 software.

\section{RESULTS AND DISCUSSION}

\section{Discriminant Validity Test}

Discriminant validity is carried out to ensure that each concept of each latent variable is different from other variables. A construct with good discriminant validity if each loading factor value of each indicator of a latent variable has the largest loading factor value with other loading values on other latent variables. The results of the discriminant validity test show that the correlation of the Green Marketing constructs with the indicator GM1 is 0.745 . However, GM2 is 0.704 ; GM4 is 0.592 ; GM5 is 0.750 ; GM6 is 0.686 ; GM7 is 0.711 ; and GM8 is 0.790, which is higher than the correlation of Green Marketing with other constructs. Furthermore, the correlation between the Brand Image construct and the BI1 indicator is 0.703; BI2 is 0.677; BI4 is 0.834; BI5 is 0.820; and BI6 is 0.782, which is higher than the correlation of Brand Image with other constructs.

Furthermore, the correlation of the Service Quality construct with its indicator SQ1 is 0.795; SQ2 is 0.770; SQ4 is 0.787 ; SQ5 is 0.574 ; SQ6 is 0.815 ; SQ7 is 0.727 ; SQ8 is 0.810 ; and SQ10 is 0.806 , which is higher than the correlation of Service Quality with other constructs. Furthermore, the correlation between the decision to stay with the indicator KM1 is 0.624 ; KM2 is 0.722 ; KM3 is 0.631 ; KM4 is 0.554 ; KM5 is 0.829 ; KM6 is 0.812 ; KM7 is 0.763 ; KM8 is 0.571 ; KM9 is 0.809 , and KM10 is 0.800 which is higher than the correlation of Decision to Stay with other constructs. Another method to see discriminant validity is to compare the value of the Square Root of Average Extracted (AVE) of each construct with the correlation between other constructs in the model, and it is said to have a discriminant validity value that is good. It can be concluded that the square root of the Average Variance Extracted (AVE) for each construct is greater than the correlation between one construct and another in the model. From the AVE value, the constructs in the estimated model meet the discriminant validity criteria.

\section{Reliability Test}

Composite Reliability and Cronbach's Alpha testing aims to test the instrument's reliability in a research model. Alternatively, measure internal consistency, and the value must be above 0.60 . If all latent variable values have Composite Reliability and Cronbach's Alpha 0.70, it means that the construct has good reliability or the questionnaire used as a tool in this study is reliable and consistent. Composite Reliability and Cronbach's Alpha testing showed a good value, i.e., all latent variables were reliable because all latent variable values had Composite Reliability and Cronbach's Alpha values 0.70 . So, it can be concluded that the questionnaire used as a research tool has been reliable or consistent.

\section{Structural Model Testing (Inner Model) a. R-Square $\left(\mathbf{R}^{2}\right)$ Value}

Looking at the R-square value, which is the goodness of fit model test

Table 4. Results of R-Square $\left(\mathrm{R}^{2}\right)$ Value Test Values

\begin{tabular}{ll}
\hline Variable & $\mathrm{R}$-Square $\left(\mathrm{R}^{2}\right)$ \\
\hline Stay Decision & 0.672 \\
\hline Source: PLS Output Results &
\end{tabular}

The table above shows that the value of R-Square (R2) or the coefficient of determination is 0.672 . It means that $67.2 \%$ variation or decision to stay is influenced by Green marketing, Brand Image, and Service Quality. In contrast, the remaining $32.8 \%$ is explained outside this research model.

\section{b. Goodness of Fit Model}

Testing the Goodness of Fit Structural model on the inner model uses predictive relevance (Q2). A Qsquare value greater than zero (0) indicates that the model has predictive relevance. The R-square value of each endogenous variable in this study was 0.672 . It means that $67.2 \%$ of the Stay Decision variable (dependent variable) variation is explained by the variables used; thus, the model is said to be feasible to have a relevant predictive value. 


\section{c. Hypothesis Testing Evaluation}

The estimated value for the path relationship in the structural model must be significant. This significance value can be obtained by bootstrapping procedure. Seeing this significance in the hypothesis by looking at the bootstrapping report algorithm's parameter coefficient values and the T-statistical significance value. In finding out the test's significance, it can be seen from the T-table at alpha $0.05(5 \%)=1.96$. Then, Ttables are compared by $\mathrm{T}$-count (T-statistics).

Table 5. Hypothesis Testing Results

\begin{tabular}{lll}
\hline & $\begin{array}{ll}\text { T Statistics } \\
(|\mathrm{O} / \mathrm{STDEV}|)\end{array}$ & $\begin{array}{l}\text { P- } \\
\text { Values }\end{array}$ \\
\hline Green Marketing $\rightarrow$ Stay Decision & 2.619 & 0.009 \\
Brand Image $\rightarrow$ Stay Decision & 2.487 & 0.013 \\
Service Quality $\rightarrow$ Stay Decision & 2.394 & 0.017 \\
\hline
\end{tabular}

Source: PLS Output Results

1) Based on the hypothesis test in the study, it was found that Green Marketing had a positive and significant effect on the decision to stay because the results of the T-statistic $>\mathrm{T}$ table $(2,619>1.96)$ and the original sample value showed a positive value. It means that Green Marketing is a strong factor and can encourage consumers to make decisions to stay.

2) Based on the hypothesis test in the study, it was found that Brand Image had a positive and significant effect on the decision to stay because the results from T-statistics $>\mathrm{T}$ table $(2,487>1.96)$ and the original sample value showed a positive value. It means that Brand Image becomes a strong factor and can encourage consumers to decide to stay.

3) Based on the hypothesis test in the study, it was found that Service Quality had a positive and significant effect on the decision to stay because the results of the T-statistic $>$ T table $(2.394>1.96)$ and the original sample value showed a positive value. It means that Service Quality is a strong factor and can encourage consumers to decide to stay.

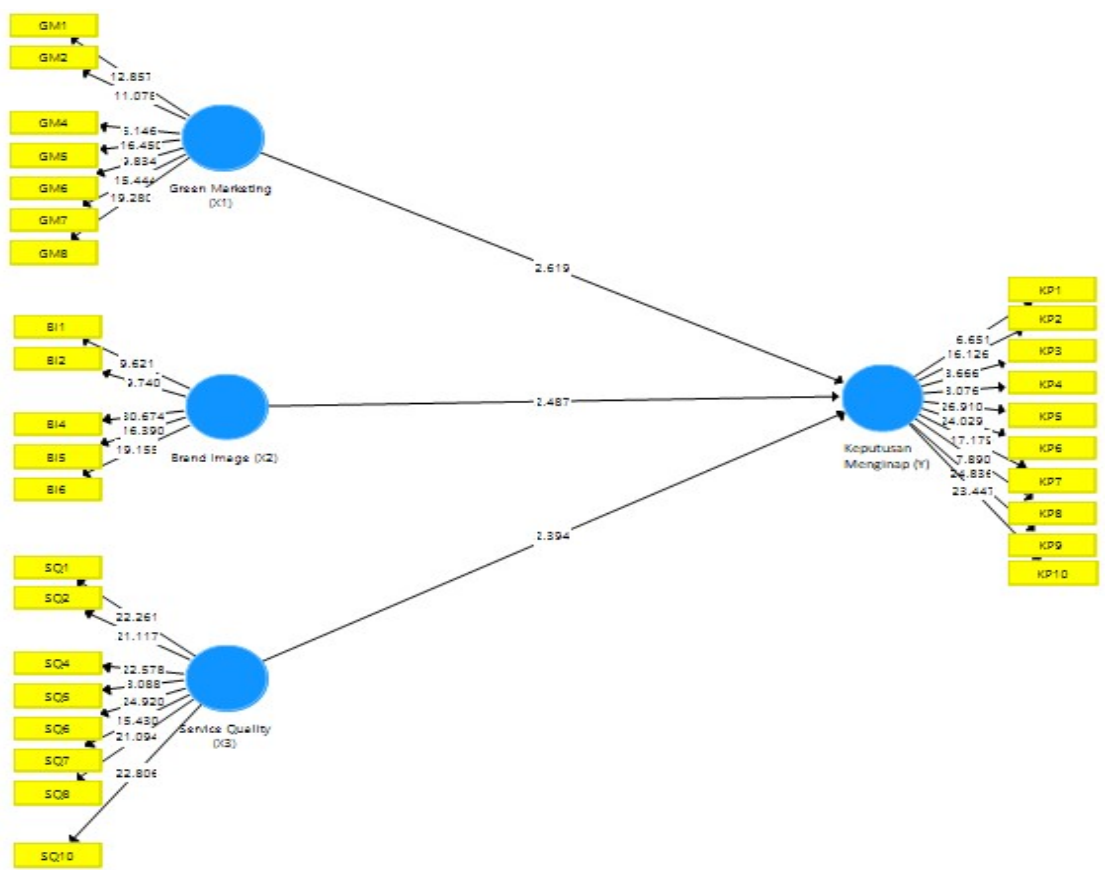

Figure 1. Bootstrapping Test Results Source: PLS Output Results 


\section{Discussion and Research Results}

\section{Effect of Green Marketing on Staying Decisions}

The first hypothesis (H1) The results of hypothesis testing in this study obtained the results of T-statistics > $\mathrm{T}$ table $(2.619>1.96)$, and the original sample value showed a positive value. These results indicate that Green Marketing has a positive and significant effect on the decision to stay. It means that Greenhost Boutique Prawirotaman, Yogyakarta, can apply the concept of Green Marketing following the needs of today's environment. It is in line with research conducted by Nikmah et al., (2018), which shows that Green Marketing has a significant positive effect on Staying Decisions. Likewise, Wati's (2018) research shows that Green Marketing has a direct and significant influence on stay decisions. According to Panungkelan (2018), showing Green Marketing has a significant influence on staying at the Swiss Bell Maleosan Manado hotel.

\section{The Influence of Brand Image on Staying Decisions}

Second Hypothesis (H2) Hypothesis Testing in this study obtained results from T-statistics $>$ T table $(2,487$ $>1.96$ ), and the original sample value showed a positive value. These results indicate that Brand Image has a positive and significant effect on the decision to stay. It means that Greenhost Boutique Prawirotaman, Yogyakarta, can form a good Brand Image through customer satisfaction to make consumers interested in deciding to stay. It is in line with Amanu's (2018) research, which shows that the Brand image variable has a positive and significant effect on the decision to stay. Likewise, according to Jumiati et al., (2017), research shows that a positive brand image will increase consumer decisions to stay at the Sala View Hotel Solo. As well as research conducted by J Rosalina. (2018) shows that brand image has a positive and significant effect on decisions to stay at Fave Hotel Ahmad Yani Bekasi.

\section{The Influence of Service Quality on Staying Decisions}

The third hypothesis (H3) is Hypothesis testing. It is in line with research conducted by Mardika (2018), showing that Service Quality affects Staying Decisions. from the T-statistic $>$ T table $(2.394>1.96)$, and the original sample value shows a positive value. These results indicate that Service Quality has a positive and significant effect on the decision to stay. It means that Greenhost Boutique Prawirotaman, Yogyakarta, can meet consumer needs and with good service quality to attract consumers to make decisions to stay. It is in line with Novitiah's (2019) research that showed that service quality positively affects stay decisions. Likewise, according to Permadi (2019), research shows that Service Quality affects decisions to stay at The Jayakarta SP AND SPA hotel (Case Study of Sp And Spa hotel consumers, Jakarta). Moreover, research was conducted by the Constitutional Court. Rumambi (2019) shows that Service Quality affects the decision to stay at Grand Luley Manado.

\section{CONCLUSION}

The results of the study found positive and significant effects: (1) Green marketing on the decision to stay; (2) The brand image on the decision to stay; (3) Service quality on the decision to stay at Greenhost Boutique Prawirotaman, Yogyakarta

\section{Suggestion}

1) The manager of Greenhost Boutique Prawirotaman, Yogyakarta, to pay more attention to the arrangement or design so that it looks exclusive according to what consumers expect so that later it can make consumers desire higher to stay at Greenhost Boutique Prawirotaman, Yogyakarta.

2) The manager of Greenhost Boutique Prawirotaman, Yogyakarta to pay more attention to the aspect of product identity, which states the product is environmentally friendly, as well as the importance of providing more detailed information about what organic products are used so that this information can increase consumer knowledge of the product and feel safer in using it.

3) For the next research, it is suggested: (a) to research with a wider population coverage area, (b) add the concept of green awareness, corporate social responsibility as a comprehensive approach to measuring purchasing decisions.

\section{REFERENCE}

Agustin, R.D. (2015). Pengaruh Green Marketing Terhadap Minat Beli Serta Dampaknya Pada Keputusan Pembelian.Jurnal Administrasi Bisnis (JAB), 22 (2). 
Amanu, W. T. L. (2018). Pengaruh Green Marketing, Green Brand Image Dan Kualitas Produk Terhadap Keputusan Pembelian Produk Sayuran Organik (Studi Kasus Pada Masyarakat Wilayah Slipi Jakarta Barat) (Doctoral dissertation, Universitas Mercu Buana Jakarta).

Arimbawa, I. G. S., \& Ekawati, N. W. (2017). Pengaruh Penerapan Green Marketing terhadap Citra Merek dan Keputusan Pembelian Produk. E-Jurnal Manajemen, 6(5), 2582-2608.

Dimyati, M., Kartikasari, M. D., \& Sukarno, H. (2018). Pengaruh Green Marketing dan Pengetahuan Terhadap keputusan Pembelian dengan Mediasi minat Membeli konsumen Sariayu Martha Tilaar di Kota Jember. e-Journal Ekonomi Bisnis dan Akuntansi, 5(2), 172-177.

Gulla, R., Oroh, S. G., \& Roring, F. (2015). Analisis Harga, Promosi, dan Kualitas pelayanan terhadap Kepuasan konsumen pada hotel Manado Grace inn. Jurnal EMBA: Jurnal Riset Ekonomi, Manajemen, Bisnis dan Akuntansi, 3(1).

Hartono, Jogiyanto. (2016). Metodologi Penelitian Bisnis (Salah Kaprah dan Pengalaman-pengalaman). Yogyakarta: BPFE.

Hawkins, Del. I, Mothersbaugh, David L. (2010). Consumer Behavior: Building Marketing Strategy, 11thEdition, New York: McGraw-Hill Irwin.

Isa, Muzakar., Mardalis, Ahmad., dan Mangifera, Liana. (2018). Analisis Keputusan Konsumen Dalam Melakukan Pembelian Makanan Dan Minuman Di Warung Hik. Daya Saing Jurnal Ekonomi Manajemen Sumber Daya, 20 (1).

Isa, M., \& Istikomah, R. (2020).Analisis Perilaku Konsumen Dalam Keputusan Pembelian Makanan di Kota Surakarta. Jurnal Manajemen Dayasaing, 21(2), 98-110.

Iskandar, H. (2020). Analisis Pengaruh Citra Merek Terhadap Keputusan Menginap Di Hotel X. Jurnal Hospitality dan Pariwisata, 6(2), 93-105

Jumiati, J., Sudarwati, S., \& Widayanti, R. (2017). Analisis Pengaruh Brand Image, Promosi, Harga, dan Lokasi Terhadap Keputusan Konsumen Memilih Menginap Dihotel Sala View Solo. Jurnal Studi Manajemen dan Bisnis, 4(2), 196-208.

Kotler dan Keller.(2012). Manajemen Pemasaran, jilid I Edisi ke 13, Erlangga Jakarta.

Kotler, Philip and Gary Amstrong. (2014). Principle of Marketing. 14 Edition. England: Pearson Education, Inc.

Manongko, A. A. C. (2015). Faktor-faktor yang berpengaruh terhadap produktivitas rumah tangga petani hortikultura di Kabupaten Minahasa (studi pendidikan ekonomi rumah tangga)/Allen A. Ch. Manongko (Doctoral dissertation, Universitas Negeri Malang).

Nikmah, F., Hasan, H., \& Mardika, E. M. P. (2018). Pengaruh Green Marketing Terhadap Keputusan Pembelian Produk Tupperware. Khazanah Ilmu Berazam, 1(2 SEPT), 1-6.

Novitiah, I. D. A. A. M. (2019). Pengaruh Kualitas Pelayanan Online (E-Service Quality) Dan Promosi Terhadap Keputusan Menginap Pada Ubud Inn Cottages Di Ubud Gianyar (Doctoral dissertation).

Nugraheni, D. P., \& Dwiyanto, B. M. (2015). Pengaruh Citra Merek, Persepsi Harga, dan Atribut Produk Terhadap Keputusan Pembelian Mobil Toyota Avanza Dengan Minat Beli Sebagai Variabel Intervening (Studi pada PT Nasmoco Majapahit Semarang) (Doctoral dissertation, Fakultas Ekonomika dan Bisnis).

Panungkelan, L., Tumbel, A., \& Tawas, H. (2018). Analisis Pengaruh Strategi Green Marketing Dan Corporate Social Responsibility Terhadap Keputusan Menginap Di Hotel Swiss Bell Maleosan Manado. Jurnal EMBA: Jurnal Riset Ekonomi, Manajemen, Bisnis dan Akuntansi, 6(3), 1178-1187

Permadi, F. Y. (2019). Pengaruh Kualitas Pelayanan, Promosi Dan Lokasi Terhadap Keputusan Menginap Di Hotel The Jayakarta Sp And Spa (Studi Kasus Pada Konsumen Hotel The Jayakarta Sp And Spa, Jakarta) (Doctoral dissertation, Universitas Mercu Buana Jakarta).

Permana, D. (2018). Pengaruh Dimensi Ekuitas Merek Terhadap Keputusan Pembelian Produk Pencuci Mulut (mouthwash). Jurnal Manajemen, 22(2), 235-250.

Prabatha, D. K. (2020).Pengaruh Kualitas Layanan Dan Kepuasan Pada Kegiatan Event Olahraga Perusahaan Repetitif Terhadap Kebahagiaan Karyawan Pt Pertamina (Persero) Refinery Unit III. FIRM Journal of Management Studies, 5(2), 99-110.

Purnama, P. A. I., \& Adi, N. R. (2019). Green Marketing dan Quality Brand Sebagai Prediktor Perilaku Konsumen dan Dampaknya Terhadap Keputusan Pembelian Produk. Jurnal Manajemen Bisnis, 16(1), 185-205.

Rani, F. P., Kusuma, H. E., \& Ardhyanto, A. (2018). Pariwisata Pusaka: Destinasi Dan Motivasi Wisata Di Pusaka Saujana Imogiri Yogyakarta. Jurnal Planologi, 15(2), 149-163.

Riyanto, M., \& Masjud, Y. I. (2017). Pengaruh Atribut Produk Terhadap Keputusan Pembelian Melalui Minat beli Sebagai Variabel Mediasi. FIRM Journal of Management Studies, 2(2), 1-12

Rosalina, J., \& Silitonga, P. (2018). Pengaruh Citra Merek, Kualitas Pelayanan Dan Lokasi Terhadap Keputusan Menginap Di Fave Hotel Ahmad Yani Bekasi. STEIN eRepository, 13(2). 
Rumambi, M. K., Soegoto, A. S., \& Jorie, R. J. (2019). Pengaruh Bauran Promosi, Harga Dan Kualitas Pelayanan Terhadap Keputusan Menginap Pada Grand Luley Manado. Jurnal EMBA: Jurnal Riset Ekonomi, Manajemen, Bisnis dan Akuntansi, 7(4).

Safera Mahendra, Y., \& Cempena, I. B. (2020). Pengaruh Kualitas Pelayanan, Fasilitas, Dan Lokasi Terhadap Kepuasan Pasien di UPT Puskesmas Kutorejo Mojokerto (Doctoral dissertation, Universitas 17 Agustus 1945 Surabaya).

Situmorang, J. R. (2011). Pemasaran hijau yang semakin menjadi kebutuhan dalam dunia bisnis. Jurnal Administrasi Bisnis, 7(2).

Soltani, M., Esfidani, M. R., Jandaghi, G., \& Soltaninejad, N. (2016).The effect of service quality on private brand image and purchase intention in the chain stores of ETKA. World Scientific News, 47(2), 202-216.

Sugianto, S. A. L. (2017). Pengaruh green product, service quality, dan brand image terhadap customer satisfaction pada The Body Shop di Surabaya (Doctoral dissertation, Widya Mandala Catholic University Surabaya).

Sumarwan, dkk. (2012). Riset Pemasaran dan Konsumen. PT Penerbit IPB Press. Bogor.

Tjiptono, Fandy. (2014). Service Quality and Satisfaction.Edisi 3. Andi Offset. Yogyakarta.

Tyas, A. A. W. P., \& Kenny, A. (2016).Pengaruh Service Quality dan Brand Image Terhadap Loyalitas Melalui Kepuasan Konsumen Pada Inul Vizta Karaoke di Jakarta (Studi Kasus Pada Kepuasan Konsumen Inul Vizta Karaoke di Jakarta). Jurnal Ekonomi Universitas Esa Unggul, 7(2), 79542.

Wardhana, A. (2015). Pengaruh Kualitas Layanan Mobile Banking (M-Banking) Terhadap Kepuasan Nasabah di Indonesia [Effect of Mobile Banking (M-Banking) Service Quality on Customer Satisfaction in Indonesia]. DeReMa (Development Research of Management): Jurnal Manajemen, 10(2), 273-284.

Yosep, C. (2016). The influence of service quality on customer satisfaction in Gran Puri Hotel Manado. Jurnal Berkala Ilmiah Efisiensi, 16(1). 